\title{
Developing a Topographic Model to Predict the Northern Hardwood Forest Type within Carolina Northern Flying Squirrel (Glaucomys sabrinus coloratus) Recovery Areas of the Southern Appalachians
}

\author{
Andrew Evans, ${ }^{1}$ Richard Odom, ${ }^{2}$ Lynn Resler, ${ }^{3}$ W. Mark Ford, ${ }^{4}$ and Steve Prisley ${ }^{5}$ \\ ${ }^{1}$ Department of Geography, Texas A\&M University, College Station, TX 77840, USA \\ ${ }^{2}$ Geospatial and Environmental Analysis Program, Virginia Polytechnic Institute and State University, Blacksburg, VA 24061, USA \\ ${ }^{3}$ Department of Geography, Virginia Polytechnic Institute and State University, Blacksburg, VA 24060, USA \\ ${ }^{4}$ Department of Fish and Wildlife Conservation, Virginia Cooperative Fish and Wildlife Research Unit, U.S. Geological Survey, \\ Blacksburg, VA 24061, USA \\ ${ }^{5}$ Department of Forest Resources and Environmental Conservation, Virginia Polytechnic Institute and State University, \\ Blacksburg, VA 24061, USA \\ Correspondence should be addressed to W. Mark Ford; wmford@vt.edu
}

Received 12 May 2014; Revised 14 July 2014; Accepted 18 July 2014; Published 28 August 2014

Academic Editor: Piermaria Corona

Copyright (C) 2014 Andrew Evans et al. This is an open access article distributed under the Creative Commons Attribution License, which permits unrestricted use, distribution, and reproduction in any medium, provided the original work is properly cited.

\begin{abstract}
The northern hardwood forest type is an important habitat component for the endangered Carolina northern flying squirrel (CNFS; Glaucomys sabrinus coloratus) for den sites and corridor habitats between boreo-montane conifer patches foraging areas. Our study related terrain data to presence of northern hardwood forest type in the recovery areas of CNFS in the southern Appalachian Mountains of western North Carolina, eastern Tennessee, and southwestern Virginia. We recorded overstory species composition and terrain variables at 338 points, to construct a robust, spatially predictive model. Terrain variables analyzed included elevation, aspect, slope gradient, site curvature, and topographic exposure. We used an information-theoretic approach to assess seven models based on associations noted in existing literature as well as an inclusive global model. Our results indicate that, on a regional scale, elevation, aspect, and topographic exposure index (TEI) are significant predictors of the presence of the northern hardwood forest type in the southern Appalachians. Our elevation + TEI model was the best approximating model (the lowest AICc score) for predicting northern hardwood forest type correctly classifying approximately $78 \%$ of our sample points. We then used these data to create region-wide predictive maps of the distribution of the northern hardwood forest type within CNFS recovery areas.
\end{abstract}

\section{Introduction}

1.1. Environmental Setting. The Blue Ridge portion of the southern Appalachians, extending from northern Georgia to central Virginia [1], has been labeled a "biodiversity hotspot" due to its assemblage of unique ecosystems and number of imperiled species that occur therein $[2,3]$. Natural and anthropogenic disturbance history has significantly altered the landscape and continues to impact the habitat of endemic species such as the endangered Carolina Northern flying squirrel (CNFS, Glaucomys sabrinus coloratus), a Pleistocene relict that uses the montane northern hardwood and red spruce (Picea rubens)-Fraser fir (Abies fraseri) forests for denning sites and foraging areas [4-6].

In the southern Appalachians, high elevation forest communities above $1200 \mathrm{~m}$ have been subjected to varying degrees of disturbance over the last 200 years. Disturbance to these areas began with Native Americans and early European pioneers clearing land for high-elevation pasture and then large-scale timber harvesting to exploit vast forest resources during the industrial logging period around the turn of the 20th century $[5,7]$. The extent and type of harvests 
during this time were important determinants for shaping the present high-elevation forests. In mid- to high-elevations, wildfires or intentional burning following logging of northern hardwoods favored regeneration of helophytic tree species, such as oak (Quercus spp.), particularly, northern red oak (Quercus rubra) [8]. Conversely, in disturbed areas where red spruce-Fraser fir were cut and burned, stump sprouting and wind dispersed seeds allowed northern hardwood species to regenerate, thereby increasing the acreage of mixed northern hardwood-red spruce stands in formerly pure conifer forests [5]. Currently, some high elevation oak stands appear to be in a transition state, moving back towards a northern hardwood forest dominated by mesic species such as maples (Acer spp.) and yellow birch (Betula alleghaniensis). This transition is occurring in a gap-phase disturbance-response condition, in the absence of fire that might otherwise favor establishment and release of oak advance regeneration. More recent perturbations include the introduction of the balsam woody adelgid (Adelges piceae), causing significant mortality of Fraser fir at the upper elevation limits of northern hardwood distribution, and the beech bark disease on American beech (Fagus grandifolia) throughout $[1,9]$. Loss of mature Fraser fir and American beech can lead to the formation of forest canopy gaps that allows the woody shrubs such as blackberry (Rubus spp.) to capture the site, keeping successional processes arrested [10]. Additionally, the southern Appalachians are known to be an area of high atmospheric acid deposition and impacts on high elevation forest health have been posited by some researchers [11-13].

Two sciurid species, the endangered CNFS and the common southern flying squirrel (SFS; Glaucomys volans), have been impacted by these past and ongoing forest changes. Both species den in cavities commonly found in older, mature deciduous trees. All CNFS are limited to isolated highelevation areas along the Appalachian crest in western North Carolina, eastern Tennessee, and southwestern Virginia, where nine "populations" are believed to exist $[4,14,15]$. Previous studies of CNFS have indicated that red spruceFraser fir forests serve as foraging areas attributed in part to the presumed higher abundance of mycorrhizal fungi that make up a significant portion of CNFS diet and serve as drey (twig or leaf nest) sites on a limited basis $[4,16-$ 18]. The northern hardwood species of these second growth forests, most commonly yellow birch (Betula alleghaniensis) or American beech (Fagus grandifolia), provide nesting sites for CNFS in the form of large hollows and cavities as well as food cache sites, latrines, and natal sites [4, 19, 20]. Weigl [6] and Meyer et al. [21] found that these sites also provide substantial ground cover and closed canopies that provide a degree of protection from predators as well as quantities of wet, decaying wood that support the truffles, lichens, and beech nuts that make up a large portion of CNFS diet. Additionally, northern hardwoods can be relatively poor habitat for the competing southern flying squirrel and can serve has habitat corridors linking red spruce-Fraser fir patches that may constitute the preferred foraging habitat [22].

However, northern hardwoods, particularly those in close proximity to oak stands with hard mast production, provide the SFS a high-energy food source. This food source has allowed the more austral SFS to overcome an otherwise thermally difficult environment and increase in abundance and local distribution at high elevations. Despite their smaller size, SFS are more aggressive than CNFS in den-site competition when the two species are synoptic, often displacing CNFS locally [5, 19, 22-24]. Moreover, SFS are chronic hosts of an intestinal nematode (Strongyloides robustus) that is often lethal to CNFS and that may have contributed further to CNFS reductions [6, 19, 25-27]. Northern hardwoods with substantial ground cover, large amounts of coarse woody debris, lichens, and closed canopies can provide some suitable foraging habitat for CNFS $[6,21]$ or serve as habitat corridors, particularly in close proximity to mixed or completely conifer-dominated stands $[5,28]$. Additionally, in the absence of oak, northern hardwoods can be relatively poor habitat for SFS [22]. As a requirement for CNFS recovery, an improved understanding of the distribution of northern hardwoods within designated CNFS recovery areas (Figure 1) is necessary for habitat delineation and identification of possible habitat management strategies to enhance and increase existing CNFS populations and local distributions [14].

1.2. Predictive Habitat Modeling. Mapping the distribution of deciduous forest types over large areas and in complex terrain is an important yet challenging task. Data from extensive vegetation inventories such as the US Forest Service Forest Inventory and Analysis program [29] and Carolina Vegetation Survey [30] are generally too coarse for accurate delineation of forest or habitat types at a management scale. Land cover mapping from aerial photography and satellite imagery can sufficiently discriminate between coniferous and deciduous forest cover but have generally not been an effective approach in distinguishing among the many deciduous forest types that dominate most southern Appalachian landscapes (e.g., discerning oak-dominated systems from northern hardwoods). Since extensive field sampling within each recovery area for the presence of CNFS is not possible, predictive models based on relationships between biophysical gradients and species distributions may provide an effective and needed approach for this management concern [31, 32].

In forested mountain landscapes, where topography controls or influences many biophysical characteristics, such as microclimate, incident solar radiation, soil moisture, and organic matter accumulation, modeling terrain attributes within a geographic information system (GIS) can be effective for delineating vegetation community patterns [1, 33-35]. Topographic characteristics that are often directly correlated with environmental gradients of interest can be accurately and efficiently modeled for large geographic areas using widely available digital elevation data and spatial analysis software [1]. Nonetheless, previous studies using GIS-based terrain analysis to predict ecological types in the southern Appalachians have been relatively limited in geographic scope $[7,15,36]$. Simon et al. [1] used topographic variables in addition to geological and soil fertility data as a first approximation to classify ecological zones of the southern 


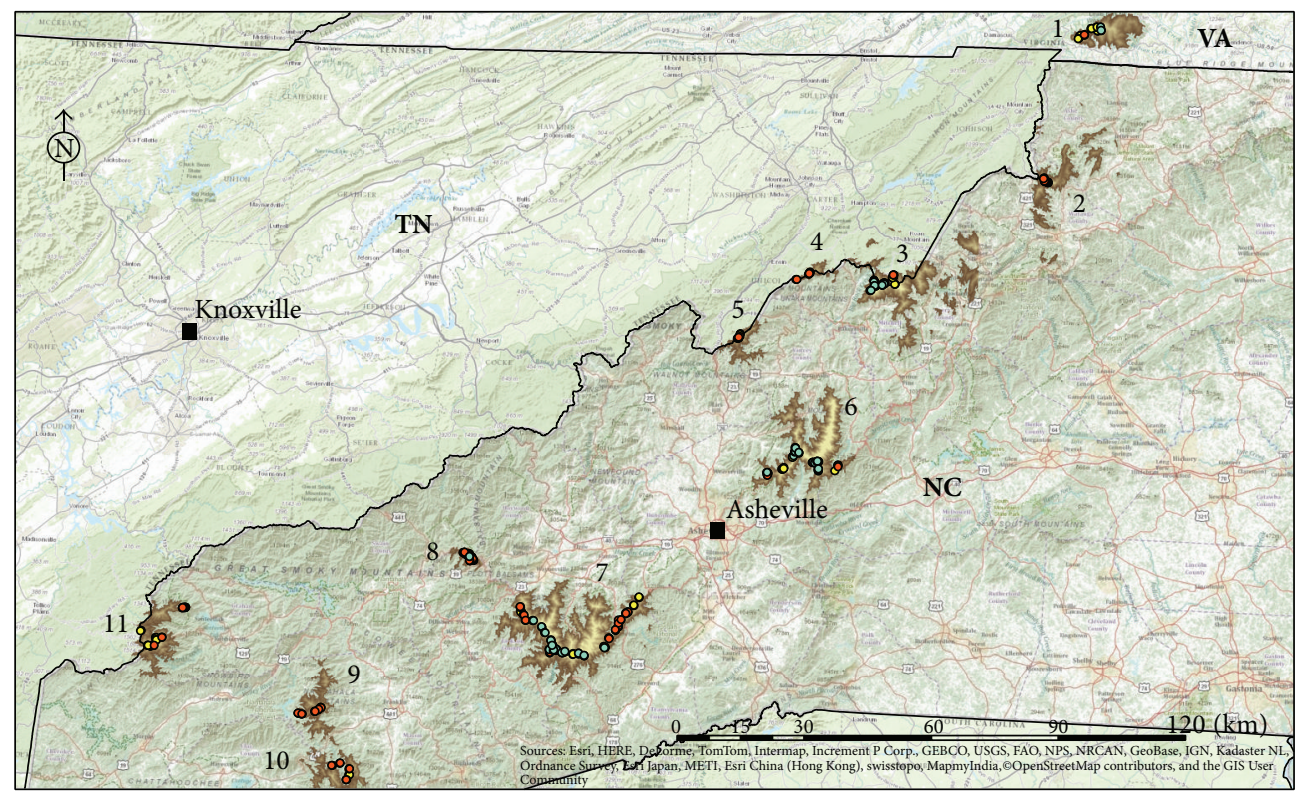

Sampling points

Forest type

- Northern hardwood

- Northern red oak

- Spruce-fir

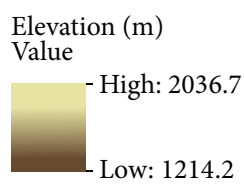

FIGURE 1: Northern hardwood study areas in Western North Carolina, eastern Tennessee, and southwestern Virginia surveyed in June 2012January 2013. Mountain ranges or massifs were (1) Grayson Highlands, (2) Elk Knob State Park, (3) Roan Mountain, (4) Unaka Mountain, (5) Big Bald, (6) Black and Craggy Mountains, (7) Great Balsams, (8), Cherokee Reservation, (9) Wayah Bald, (10) the Standing Indian, and (11) Unicoi Mountains. All of these ranges are believed to have populations of Carolina Northern flying squirrel with the exception of the Wayah Bald and the Standing Indian.

Appalachians with GIS outputs achieving 81 and 85 percent accuracy for the northern hardwood forest type in their northern and southern zones. However, the lack of distinction between predicted northern hardwood forests and high-elevation oak forests limits management utility. Furthermore, a more precise model of the northern red oak forest types, northern hardwood forests, and their ecotone would allow forest managers to more appropriately use prescribed burning to accomplish burning goals to favor oak where it is biologically appropriate without harming fire-sensitive northern hardwood or red spruce-Fraser fir regeneration. Lastly, a predictive model would provide a baseline condition for predicting the impact of climate change in the southern Appalachians to high elevation forest types such as northern hardwoods that are presumed to be a risk for decline.

The objectives of our study were to define the northern hardwood forest type in western North Carolina, adjacent portions of eastern Tennessee, and southwestern Virginia and to determine if the geographic distribution of northern hardwood forest types can be accurately determined from digital terrain modeling in and adjacent to CNFS recovery areas. To meet the objectives, we used a decision tree approach for initial classification based on similar stand composition and species abundance within those stands as used in previous studies $[1,33,37]$. We examined presence or absence of northern hardwoods at high elevations in the region using an information-theoretic approach [38]. We hypothesized, based on previous studies, that elevation, aspect, slope, curvature, and an index of topographic exposure would contribute to the predictive model [7, 34, 39-41].

\section{Methods}

2.1. Study Areas. During the summer of 2012 and January 2013, we sampled vegetation and terrain characteristics at 338 points over 113 three-point belt transects across 11 study areas in western North Carolina, adjacent portions of eastern Tennessee, and southwestern Virginia within the Blue Ridge physiographic province (Figure 1). Nine sites were within North Carolina and/or portions of Tennessee along the crest of the southern Appalachians or in the Grayson Highlands area of southwestern Virginia that contained known populations of CNFS $[6,16,42]$. Additionally, we sampled two, more disjunct high-elevation areas in North Carolina with northern hardwood forests where CNFS have not been documented-the Standing Indian and Wayah Bald massifs. All sample points fell within the Blue Ridge Parkway National Park (BRPNP), Pisgah, Nantahala, Cherokee, or Jefferson national forests or on lands owned by the Eastern Band of Cherokee Indians. On average, these areas receive in excess 
of 200 centimeters of precipitation annually, distributed relatively evenly throughout the year (often occurring as snow and ice during the winter months). Temperatures are widely variable throughout the year due to the effects of elevation and aspect, with means of approximately $2.2^{\circ} \mathrm{C}$ in January and approximately $23^{\circ} \mathrm{C}$ in July $[1,33,43]$. Typically, the first frost occurs in early October and the last frost in early May, with 130 frost-free days on average (NOAA, National Climatic Data, 2012, http://www.ncdc.noaa.gov/cdo-web/datasets). Soils in the study area are acidic and frigid. Depending on the amount of emergent rock, soils often display deep organic layers $[17,39,44]$.

Regionally, Simon et al. [1] and Ulrey [36] characterized southern Appalachians northern hardwoods as those forests dominated by American beech, yellow birch, red maple (Acer rubrum), sugar maple (Acer saccharum), black cherry (Prunus serotina), and yellow buckeye (Aesculus octandra). This ecological group was then divided into 4 different subgroups: boulder fields, beech gaps and slopes, rich coves, and typic subtype northern hardwood $[1,36]$. The boulder field subgroup has a canopy that is dominated by yellow birch, whereas the beech gap and slopes are almost exclusively American beech $[1,7,36,45,46]$. Rich coves are composed of all of the listed species with no single dominant species and may also have mesophytic species such as basswood (Tilia americana), white ash (Fraxinus americana), silverbell (Halesia carolina), and eastern hemlock (Tsuga canadensis) [1, 36]. The typical northern hardwood subgroup is dominated by yellow birch, American beech, yellow buckeye, and sugar maple with northern red oak or red spruce individuals occasionally present but rarely dominant in the stand composition $[1,7,36,45]$. The high elevation red oak forest type also occurs frequently at this elevation range but is typically found on more xeric and exposed landforms (southerly aspects and ridge tops below the red spruce-Fraser fir zone). The oak type is more fire tolerant than the northern hardwood forest. At higher elevations in the study area, forests increasingly are dominated by red spruce and Fraser fir, although northern hardwood species are often present until elevations exceed $1800 \mathrm{~m}[1,7,36,45]$. Although there are some old-growth northern hardwood stands in the Great Smoky Mountains National Park, virtually all of the area we examined and that is extant on the landscape can be considered mature, second growth that originated after logging in the early 20th century [45, 47-49].

Using a method to validate DEM-based models similar to the approach of Odom and McNab [7], we used ESRI's ArcMap [50] to randomly select sampling points in clipped US Geological Survey (USGS) DEMs downloaded from the National Elevation Dataset (NED) [51, 52]. These sampling points served as center points on $200 \mathrm{~m}$ belt transects with sampling points placed at $0 \mathrm{~m}, 100 \mathrm{~m}$, and $200 \mathrm{~m}$. This was done in order to maximize the topographic effects on the data based on our previous knowledge of the study area terrain. For accessibility, we generated study points that were within 1000 m of the Blue Ridge Parkway or US Forest Service (USFS) roads or established hiking trails. An excess of points was originally generated to allow for the elimination of points in the field that occurred in nonforested areas (e.g., grassy balds or ericaceous heath communities) or in areas where sampling was prohibited by the National Park Service (NPS) or USFS.

The number of points we established per study area was proportional to the total area above 1219.2.2 $\mathrm{m}$ in each. Sampling rates ranged between $0.2 \%$ for the larger mountain ranges and $3 \%$ on the smaller massifs. Our sampling points in 8 of the 11 study areas met the following criteria: elevation $>1219.2 \mathrm{~m}$, within a designated CNFS recovery area, and reasonably accessible. The remaining 3 study areas included one area without documented CNFS populations but met our elevation criteria, and northern hardwood forest species were known to be present there. The lower elevation limit of $1219.2 \mathrm{~m}$ was based on the lowest recorded elevation of CNFS capture regionally [14] and also approximates where mid-elevation forest types transition to high-elevation types in the southern Appalachians [45, 53].

We used a mapping grade Trimble GeoXT GPS unit (the use of any trade, product, or firm names does not imply endorsement by the US government) with submeter accuracy to navigate to the randomly generated study points that were generated from the DEMs. At each sampling point, we tallied the total number of stems for each tree species using a 10factor basal area prism to identify dominant overstory species and made a visual determination of forest type. We noted dominant understory woody species to aid in classifying sample locations as northern hardwood or other forest types. We also looked for any evidence of past forest disturbance such as cut stumps, old logging roads/skidder trails, or abandoned railroad grades which may have influenced stand development. Our forest type categories included northern hardwood (yellow birch, American beech, sugar maple, mountain maple (Acer spicatum), basswood, and yellow buckeye), red spruce-Fraser fir, high elevation northern red oak (dominated by northern red oak with an element of American beech), and montane pine (composed mostly of table mountain pine (Pinus pungens) with pitch pine (Pinus rigida) present at some locations). A decision tree encompassing these definitions and descriptions for forest types was used for continuity throughout our study duration; we acknowledged that some species overlap may occur between forest types due to the large variation in terrain conditions and geographic extent of the study area $[1,7,34,36,45$, 54].

We classified each study point as ridgeline, shoulder, side slope, or cove and further characterized each point by its vertical position on the slope (low, medium, or high) to describe each point's location and topographic position in relation to the surrounding landscape [55]. We collected elevation, slope gradient, and aspect measurements at each study point in the field using GPS, a clinometer, and a compass, respectively, following methods described by $\mathrm{McNab}$ et al. [9]. Aspect was measured in the direction of the steepest downward slope and we recorded slope gradient from the sampling point to a point approximately $15 \mathrm{~m}$ away in the same direction.

2.2. Deriving Terrain Variables. We downloaded USGSproduced 1/3 arc-second (10 meter) digital elevation models 
TABLE 1: Mean terrain attributes of the three forest types in the areas above 1219.2.2 $\mathrm{m}$ in elevation of western North Carolina, eastern Tennessee, and southwest Virginia which composed our study area $(n=332)$. Sampling took place between June 2012 and January 2013.

\begin{tabular}{|c|c|c|c|c|}
\hline & & \multicolumn{3}{|c|}{ Forest type } \\
\hline & & Northern hardwood & Northern red oak & Red spruce-Fraser fir \\
\hline \multirow{7}{*}{ Terrain attribute } & $N$ & 179 & 80 & 73 \\
\hline & Northing (UTM) & 3952592.87 & 3932901.42 & 3954948.38 \\
\hline & Elevation (m) & 1528.03 & 1443.59 & 1704.28 \\
\hline & Aspect (degrees) & 198.89 & 195.73 & 195.49 \\
\hline & Slope (percent) & 35.63 & 35.51 & 34.63 \\
\hline & Curvature & 0.23 & 0.86 & 0.44 \\
\hline & TEI* & 58.27 & 60.14 & 81.81 \\
\hline
\end{tabular}

${ }^{*}$ Topographic exposure index.

$[51,52]$ for each study area and derived 5 terrain variables (elevation, slope gradient, aspect, topographic exposure index, and slope curvature). Slope gradient was computed using the 4-cell method in DEM Surface Tools [56] and aspect was calculated using ArcGIS Spatial Analyst and then transformed using a sin transform. Topographic exposure index (TEI) was derived by subtracting the average elevation of an area (defined as a circular area with radius equal to $1000 \mathrm{~m}$ ) surrounding each cell in the DEM from the elevation at each cell. Cells with relatively high TEI values (approximately $>50$ ) represent exposed peaks and ridges, while low values (approximately $<-50$ ) represent sheltered landforms such as coves and lower slopes. The Raster Calculator tool in ArcGIS Spatial Analyst was used to derive TEI. We derived curvature values using the algorithm identified by Moore et al. [57] as a way to describe hydrological catchment areas whereby DEM Surface tools multiply the curvature values by negative 1 and then by 100 to maintain consistency with the values calculated by ArcGIS [56]. Once these terrain surfaces were calculated for all study areas, we overlaid a vector point file of sample locations and extracted terrain values for each sample point.

2.3. Statistical Analysis. We created a series of six overarching a priori model categories to examine presence or absence of the northern hardwood forest type based on previous research findings reporting the effects of topography on regional forest types plus a global model. In addition to topographic effects, we included our northing coordinate for each sample point as a measure of latitude to examine the change in south to north elevation clines for northern hardwood presence. The model categories we constructed were based on inclusion of the following variables: (1) Elevation [41], (2) Elevation + TEI [7], (3) Elevation + Aspect [39], (4) Elevation + Curvature [34, 58], (5) Slope gradient + TEI [37], (6) Elevation + Aspect + Slope gradient [40], and (7) Global using all parameters.

We used correlation analysis to examine multicollinearity and redundancy relationships among variables and eliminated those variables with a correlation coefficient greater than 0.8 , proceeding with the variable believed to be most beneficial to analysis [59]. We then used the forest type as a categorical response and the derived terrain variables and a latitudinal gradient as predictors in a multinomial regression using the $R$ statistical software [60] and the neural network package [61]. In addition to the main effects, all interactions among variables, as well as quadratic effects of individual variables, were examined to allow for examination of a nonlinear relationship between a predictor variable and a response $[62,63]$. The multinomial regression technique uses a set of binomial comparisons to classify data as one of our three possible outcomes. The resulting equations are based on the target or reference group (northern hardwood) versus one of the other possible outcomes (northern red oak or sprucefir). The result is a probability for each possible outcome for each data point. We then classified the data points to one of three forest types that corresponded to the highest probability. We used Akaike information criteria corrected for small sample sizes (AICc) to avoid overfitting of the model to the dataset [64]. We ranked all of the models based on their respective AICc scores and considered the model with the lowest AICc score the best approximating [38]. To further examine performance of our best approximating model, we used a bootstrap procedure to compute an overall correct classification rate as well as model specificity and sensitivity to correctly predict the northern hardwood forest type. We then took the best performing model and created a predictive map using the study area terrain rasters in the $R$ statistical software package [60] that executed the model on a cell by cell basis and classified each as one of the three forest types. We then wrote these predicted cell classifications to georectified tiff image and exported it to ArcGIS for visual inspection.

\section{Results}

3.1. Model Selection and Prediction Accuracy. The 338 sites we sampled encompassed a wide range of terrain conditions (Table 1); 179 were characterized as the northern hardwood forest type and the remaining 153 sites were composed of the high elevation northern red oak forest type $(n=80)$ and the red spruce-Fraser fir forest type $(n=73)$. The montane pine community $(n=6)$ was dropped from the analysis due to the low rate of sampling. The northern hardwood forest type was found most often in sheltered areas at higher elevations than either the high elevation northern red oak forest type or montane pine communities but was consistently found at lower elevations than the red spruce-Fraser fir forest type. 
TABLE 2: Logistic regression models explaining the influence of terrain variables on the presence or absence of northern hardwoods $(\mathrm{NH})$ in the areas above 1219.2.2 $\mathrm{m}$ in elevation of western North Carolina, eastern Tennessee, and southwest Virginia which composed our study area $(n=332)$. Sampling took place between June 2012 and January 2013. Model rankings were based on Akaike's information criterion corrected for small sample size (AICc).

\begin{tabular}{lcccc}
\hline Model & $K^{\mathrm{A}}$ & $\mathrm{AICc}$ & $\Delta \mathrm{AICc}^{\mathrm{B}}$ & $R^{{ }^{\mathrm{C}}}$ \\
\hline Elevation + TEI & 8 & 488.30 & 0.00 & 0.449 \\
Elevation & 6 & 523.04 & 34.74 & 507.05 \\
Elevation + Curvature & 8 & 525.11 & 36.81 & 493.12 \\
Elevation + Aspect & 8 & 534.48 & 46.18 & 502.48 \\
Elevation + Slope + Aspect & 10 & 554.59 & 66.29 & 490.59 \\
Slope + TEI & 6 & 670.78 & 182.48 & 638.78 \\
Global & 15 & 701.89 & 213.59 & 652.45 \\
\hline
\end{tabular}

${ }^{\mathrm{A}}$ Number of parameters + I in approximating model.

${ }^{\mathrm{B}}$ Difference between current model and best approximating model (minimum AICc).

${ }^{\mathrm{C}} \mathrm{Cox}$ and Snell's re-scaled $R^{2}$.

Ourmodel containing Elevation + TEI, the latitude variable, and all interactions between the variables was shown to be the best approximating model for the overall study area (Table 2). Elevation + TEI indicated that the predicted occurrence of the northern hardwood forest type was negatively correlated with elevation and TEI when compared to the northern red oak forest type, but positively correlated when compared to the spruce-fir forest type (Table 3). Of all of the terrain variables we examined, the elevation variable was significant $(P<0.05)$ across all of the models. Our elevation + TEI model had an overall accuracy rate of $67 \%$ for all forest types but was significantly better at predicting our target forest type (northern hardwood) with an $80 \%$ accuracy rate (see Table 4). We then created a predictive map for our study using this equation (Figure 2). Our predictive map was overlaid with existing forestry data for post hoc visual analysis of misclassified points. Visual inspection showed that a large portion of the misclassified points occurred near the edges and areas where our predicted forest types overlapped with other forest types from existing forestry data sets. This likely indicates that many of the misclassified points were ecotone areas with similar probability values in more than one of our forest types.

\section{Discussion}

Our use of GIS to delineate northern hardwood forests in the southern Appalachians gives managers in the region a tool to better understand the distribution and composition of high-elevation forests important for the management and recovery of CNFS as well as other species restricted to high elevation forests. Previous studies have indicated that using digital terrain analysis within a GIS, most physiographic regions can be modeled with some degree of accuracy in the southern Appalachians [7, 34, 65, 66]. Our models show that a perceptible relationship exists between the northern hardwood forest type and some of the variables we examined.
Our Elevation + TEI model was the best model for the study area as a whole.

Our best model, Elevation + TEI, supports the current assertion that elevation plays a key role, as does the level of "shelteredness" of a point for determining the presence of the northern hardwood forest type $[15,36,37,67,68]$. The significance of the quadratic effects of the elevation variable clearly suggests that this is not a linear relationship but is influenced by other attributes of a specific site such as TEI. Others in the region also have indicated the role of an elevational gradient in combination with other site factors on stand development in the southern Appalachians $[1,36,44,69,70]$.

Our results also show that there was significant overlap in the range of several of the terrain variables we examined between the northern hardwood forest type and the adjacent red spruce-Fraser fir, high elevation northern red oak, and montane pine community. This can be attributed to the northern hardwood forest type having a higher mean elevation than the northern red oak forest type regionally but a lower mean elevation than the red spruce-Fraser fir forest type (Table 1). Additionally, the overlap in the other terrain variables is likely due to the wide variation in terrain occupied by all the forest types examined. It also supports our hypothesis and that of others that as elevation increases, aspect plays a smaller role in determination of forest type in montane systems [39]. Our Elevation + TEI model appears to follow the trend of northern hardwoods occupying more sheltered areas below ridgelines and away from exposed shoulder areas as based on field observations of others $[1,36]$. Our model accuracy was congruent with accuracy rates for other vegetation models in the study area, which range from less than 50\% [34] to $86 \%$ [7]. Inclusion of additional variables such as a soil related variable or factoring in disturbance history, that is, past fire history, would have likely increased our model's accuracy and merit further examination.

The variance in significance among predictors between the models on the overall study area also shows the complexity of the effects of latitude, terrain, site quality, and disturbance patterns on stand composition in the southern Appalachians. Terrain, site quality, and disturbance patterns are directly related to stand development regionally. However, past exploitative logging [71] and other disturbances such as conversion to pastoral system lead to burning and clearing of large areas of forest with subsequent nonanalog successional trajectories that disrupted some of the predictable association patterns in the southern Appalachians over the past 100+ years $[7,44,47,72]$.

The acreage of the northern hardwood forest type in the southern Appalachians is likely to increase as this forest type continues to reoccupy areas previously occupied by oak communities. Fire suppression that began in the 1940's has allowed for conditions to favor mesophytic species commonly associated with the northern hardwood forest type such as American beech, yellow birch, and maples to increase in abundance in the advance regeneration pool $[8,73]$. In the absence of disturbance such as fire and significant canopy removal, the high elevation northern red oak forests may become restricted to the more xeric or exposed mid-elevation 
TABLE 3: The best approximating logistic model (Elevation + TEI) explaining presence or absence of northern hardwoods in areas above 1219.2.2 $\mathrm{m}$ in elevation of western North Carolina, eastern Tennessee, and southwest Virginia which composed our study area $(n=332)$. Sampling took place between June 2012 and January 2013. Forest types are notated as follows: northern hardwood (NH), northern red oak (NRO), and red spruce-Fraser fir (RSFF).

\begin{tabular}{|c|c|c|}
\hline Parameter (NH versus NRO) & Estimate & Std. error \\
\hline Intercept & $3.61 e-10^{*}$ & $1.048 e-14$ \\
\hline Northing & $2.31 e-7^{*}$ & $4.15 e-08$ \\
\hline Elevation & $-0.007^{*}$ & $1.52 e-11$ \\
\hline TEI & $0.007^{*}$ & $1.30 e-12$ \\
\hline (Northing-3948504) $*($ Northing-3948504) & $-1.68 e-05$ & $9.95 e-10$ \\
\hline (Elevation-1550.4) $*($ Elevation-1555.4) & $-0.007^{*}$ & $1.75 e-12$ \\
\hline$(\mathrm{TEI}-47.58) *(\mathrm{TEI}-47.58)$ & 0.007 & $1.26 e-125$ \\
\hline (Elevation-1550.4) $*($ TEI-64.4693) & $-5.33 e-05^{*}$ & $6.22 e-11$ \\
\hline (Northing-3948504) $*$ (Elevation-1550.4) & $-9.03 e-08$ & $3.83 e-08$ \\
\hline (Northing-3948504) $*($ TEI-64.4693) & $-1.12 e-07$ & $1.14 e-07$ \\
\hline (Northing-3948504) $*$ (Elevation-1550.4) $*($ TEI-64.4693) & $-2.88 e-10$ & $5.05 e-10$ \\
\hline Parameter (NH versus RSFF) & Estimate & Std. error \\
\hline Intercept & $-1.38 e-11$ & $1.14 e-14$ \\
\hline Northing & $-3.90 e-06$ & $4.46 e-08$ \\
\hline Elevation & $0.009^{*}$ & $1.86 e-11$ \\
\hline TEI & $-0.006^{*}$ & $9.06 e-13$ \\
\hline (Northing-3948504) $*$ (Northing-3948504) & $-4.15 e-06$ & $9.39 e-10$ \\
\hline (Elevation-1550.4) $*($ Elevation-1555.4) & $0.009^{*}$ & $1.21 e-12$ \\
\hline$(\mathrm{TEI}-47.58) *(\mathrm{TEI}-47.58)$ & -0.007 & $4.36 e-13$ \\
\hline (Elevation-1550.4) $*($ TEI-64.4693) & $1.42 e-05$ & $6.09 e-11$ \\
\hline (Northing-3948504) $*($ Elevation-1550.4) & $9.18 e-08$ & $3.71 e-08$ \\
\hline (Northing-3948504) $*($ TEI-64.4693) & $-3.33 e-08$ & $8.38 e-08$ \\
\hline (Northing-3948504) $*$ (Elevation-1550.4) $*($ TEI-64.4693) & $-2.88 e-10$ & $5.02 e-10$ \\
\hline
\end{tabular}

* Indicates significance at the $P<0.001$.

TABLE 4: Confusion matrix for our best approximating model (Elevation + TEI) showing predicted versus observed forest types for sample points in areas above 1219.2.2 $\mathrm{m}$ in elevation of western North Carolina, eastern Tennessee, and southwest Virginia which composed our study area $(n=332)$. Sampling took place between June 2012 and January 2013. Overall accuracy for the prediction of all three forest types was $67 \%$ and for the northern hardwood forest type $80 \%$.

\begin{tabular}{|c|c|c|c|c|c|}
\hline & \multirow{2}{*}{ Forest types } & \multicolumn{4}{|c|}{ Predicted } \\
\hline & & Northern hardwood & Northern red oak & Spruce-fir & Total \\
\hline \multirow{4}{*}{ Observed } & Northern hardwood & 143 & 22 & 14 & 179 \\
\hline & Northern red oak & 39 & 41 & 0 & 80 \\
\hline & Spruce-fir & 34 & 1 & 38 & 73 \\
\hline & Total & 216 & 64 & 52 & 332 \\
\hline
\end{tabular}

slopes regionally, thereby allowing for expansion of the northern hardwoods overall [73].

Conversely, both climate change and atmospheric deposition continue to threaten the red spruce-Fraser fir forests of the southern Appalachians likely resulting in the northern hardwood forest type expanding as temperature and environmental conditions shift $[41,74,75]$. How potential replacement of these conifer stands by northern hardwoods will impact CNFS is not fully known. Still, our predictive maps in combination with additional variables such as proximity to red spruce-Fraser fir forests could help prioritize where to conduct conservation or management activities to support habitat conditions favorable to CNFS and unfavorable to SFS.
For example, applications of our map showing the locations of the northern hardwoods would allow land managers to better identify areas to avoid prescribed burning (used to promote or maintain oak stands) or identify areas to "release" understory red spruce as management actions favoring CNFS $[5,23,28,76]$. Conversely, incongruence in our map of predicted northern hardwood absence and actual presence shows managers where application of prescribed burning to restore or promote oak would be more or less appropriate.

These models could have significant implications in management practices when used in combination with known areas of red spruce and Fraser fir. A more specific habitat management and conservation plan could be developed for 

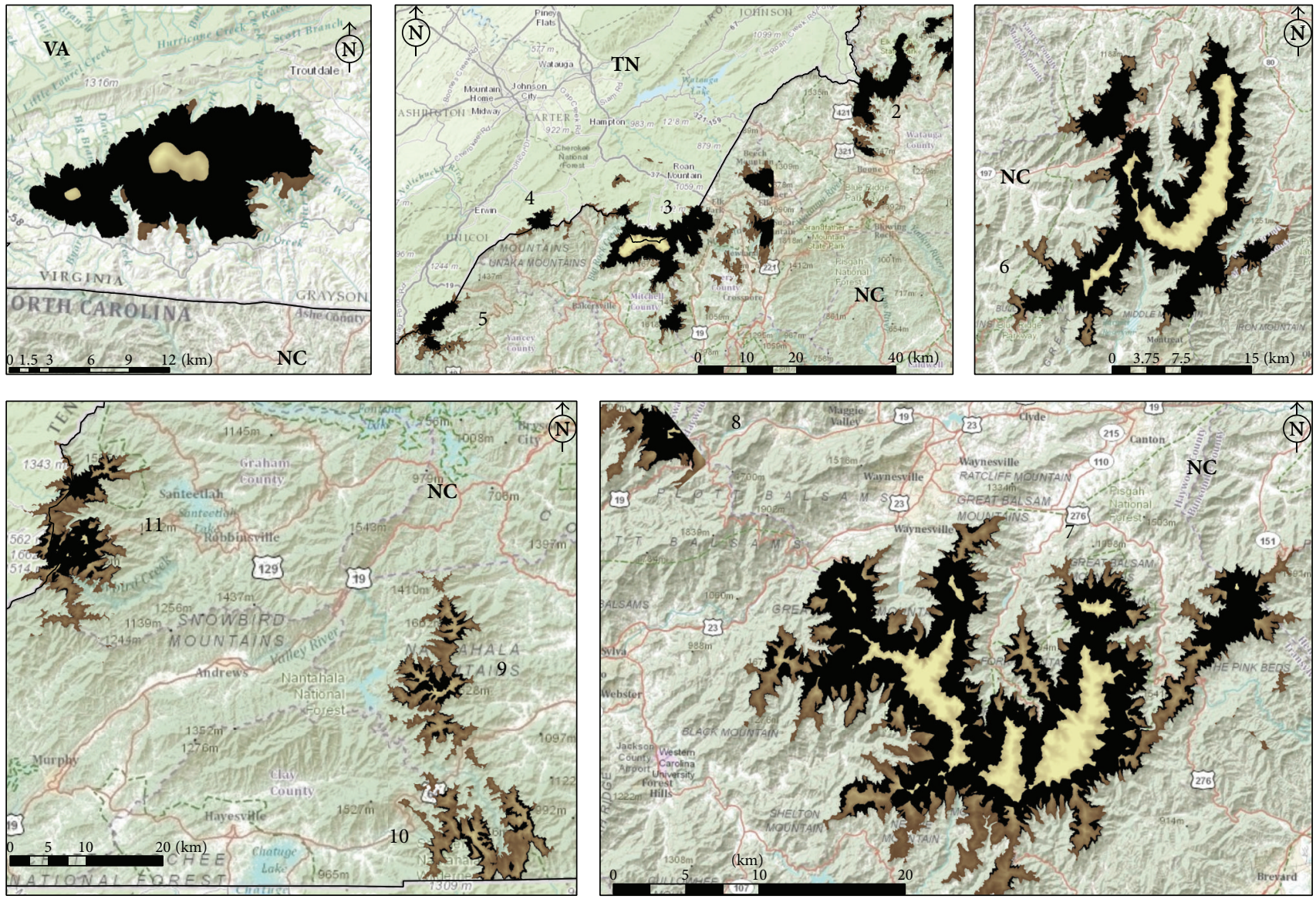

Predicted

Northern hardwood

Forest type

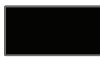

Elevation $(\mathrm{m})$

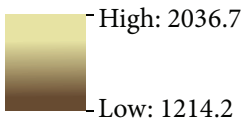

FIGURE 2: Predictive map for the study area created using the elevation + TEI model showing predicted northern hardwood forest type that was surveyed in June 2012-January 2013. Areas are numbered to correspond with map in Figure 1.

CNFS with available resources channeled to a more focused area. It also increases the likelihood that this species may occupy a larger portion of the landscape than previously suspected and raises the possibility of the existence of a larger population of this species and that recovery efforts may be more successful than previously thought. However with the current threats to the high elevation ecosystems, it will be crucial to continue to gather onsite data for much of this area. Further analysis and inclusion of additional variables would be needed to increase the predictive power of the models examined due to the influence of the variability of points occupied by the northern hardwood forest type. Using a combination of existing forestry data and land cover data from satellite imagery analysis, our predictive map of northern hardwoods could be used for a second step of pruning our incorrect classifications. As such, the combination of predicted northern hardwood distribution and existing land cover data will make it possible for managers to identify and put into practice management policies that will help conserve and improve areas such as recovery areas for CNFS as well as other stewardship goals.

\section{Conflict of Interests}

The authors declare that there is no conflict of interests regarding the publication of this paper. 


\section{Acknowledgments}

Funding for this study was provided by the US Geological Survey, Cooperative Research Unit Program, the Eastern band of Cherokee Indians, and the Department of Geography at Virginia Tech's Sidman Poole Foundation Trust. Additional logistic support was provided by the US Forest Service Southern Research Station, Bent Creek Experimental Forest. The authors thank M. Duncan for field assistance and $\mathrm{H}$. McNab for assistance with study design and field methodologies.

\section{References}

[1] S. A. Simon, T. K. Collins, G. L. Kauffman, W. H. McNab, and C. J. Ulrey, Ecological Zones in the Southern Appalachians: First Approximation, U.S. Department of Agriculture, U.S. Forest Service, Southern Research Station, Asheville, NC, USA, 2005.

[2] R. F. Noss, E. T. LaRoe III, and J. M. Scott, Endangered Ecosystems of the United States: A Preliminary Assessment of Loss and Degradation, Department of the Interior, National Biological Service, Washington, DC, USA, 1995.

[3] B. A. Stein, "A fragile cornucopia-assessing the status of US biodiversity," Environment, vol. 43, no. 7, pp. 10-22, 2001.

[4] P. D. Weigl, T. W. Knowles, and A. C. Boynton, The Distribution and Ecology of the Northern Flying Squirrel, Glaucomys sabrinus coloratus in the Southern Appalachians, North Carolina Wildlife Resources Commission, Raleigh, NC, USA, 1999.

[5] W. M. Ford, S. L. Stephenson, J. M. Menzel, D. R. Black, and J. W. Edwards, "Habitat characteristics of the endangered Virginia northern flying squirrel (Glaucomys sabrinus fuscus) in the central Appalachian Mountains," The American Midland Naturalist, vol. 152, no. 2, pp. 430-438, 2004.

[6] P. D. Weigl, "The Northern flying squirrel (Glaucomys sabrinus): a conservation challenge," Journal of Mammalogy, vol. 88, no. 4, pp. 897-907, 2007.

[7] R. H. Odom and W. H. McNab, Using Digital Terrain Modeling to Predict Ecological Types in the Balsam Mountains of Western North Carolina, U.S. Department of Agriculture, Forest Service, Southern Research Station, Asheville, NC, USA, 2000.

[8] G. J. Nowacki and M. D. Abrams, "The demise of fire and "mesophication" of forests in the eastern United States," BioScience, vol. 58, no. 2, pp. 123-138, 2008.

[9] W. H. McNab, S. A. Browning, S. A. Simon, and P. E. Fouts, "An unconventional approach to ecosystem unit classification in western North Carolina, USA," Forest Ecology and Management, vol. 114, no. 2-3, pp. 405-420, 1999.

[10] K. J. K. Gandhi and D. A. Herms, "Direct and indirect effects of alien insect herbivores on ecological processes and interactions in forests of Eastern North America," Biological Invasions, vol. 12, no. 2, pp. 389-405, 2010.

[11] M. B. Adams and C. Eagar, "Impacts of acidic deposition on high-elevation spruce-fir forests: results from the Spruce-Fir Research Cooperative," Forest Ecology and Management, vol. 51, no. 1-3, pp. 195-205, 1992.

[12] E. R. Cook and S. M. Zedaker, "The dendroecology of red spruce decline," in Ecology and Decline of Red Spruce in The Eastern United States, pp. 192-231, Springer, New York, NY, USA, 1992.

[13] C. L. Shaver, K. A. Tonnessen, and T. G. Maniero, "Clearing the air at Great Smoky Mountains National Park," Ecological Applications, vol. 4, no. 4, pp. 690-701, 1994.
[14] U. S. Fish and Wildlife Service, "Annapolis Field Office and Wildlife Service. Region 5. Appalachian northern flying squirrels (Glaucomys sabrinus fuscus)(Glaucomys sabrinus coloratus) recovery plan," U. S. Department of Interior, US Fish and Wildlife Service, Annapolis Field Office.

[15] C. McGrath and S. Patch, "Using a terrain based vegetation model to map carolina northern flying squirrel distribution," in Proceedings of the Annual Conference of Southeast Association of Fish and Wildlife Agencies, vol. 57, pp. 243-251, 2003.

[16] J. L. Payne, D. R. Young, and J. F. Pagels, "Plant community characteristics associated with the endangered northern flying squirrel, Glaucomys sabrinus, in the southern Appalachians," The American Midland Naturalist, vol. 121, no. 2, pp. 285-292, 1989.

[17] S. C. Loeb, F. H. Tainter, and E. Cázares, "Habitat associations of hypogeous fungi in the southern appalachians: implications for the endangered northern flying squirrel (Glaucomys sabrinus coloratus)," The American Midland Naturalist, vol. 144, no. 2, pp. 286-296, 2000.

[18] C. Bird and C. McCleneghan, "Morphological and functional diversity of ectomycorrhizal fungi on Roan Mountain (NC/TN)," Southeastern Naturalist, vol. 4, no. 1, pp. 121-132, 2005.

[19] P. D. Weigl, "Resource overlap, interspecific interactions and the distribution of the flying squirrels, Glaucomys volans and G. sabrinus," The American Midland Naturalist Journal, vol. 100, no. 1, pp. 83-96, 1978.

[20] H. M. Hackett and J. F. Pagels, "Nest site characteristics of the endangered Northern flying squirrel (Glaucomys sabrinus coloratus) in Southwest Virginia," American Midland Naturalist, vol. 150, no. 2, pp. 321-331, 2003.

[21] M. D. Meyer, D. A. Kelt, and M. P. North, "Nest trees of northern flying squirrels in the Sierra Nevada," Journal of Mammalogy, vol. 86, no. 2, pp. 275-280, 2005.

[22] J. M. Menzel, W. M. Ford, J. W. Edwards, and T. M. Terry, "Home range and habitat use of the Vulnerable Virginia northern flying squirrel Glaucomys sabrinus fuscus in the Central Appalachian Mountains, USA," Oryx, vol. 40, no. 2, pp. 204-210, 2006.

[23] J. M. Menzel, W. M. Ford, J. W. Edwards, and M. A. Menzel, "Nest tree use by the endangered Virginia northern flying squirrel in the central Appalachian Mountains," The American Midland Naturalist, vol. 151, no. 2, pp. 355-368, 2004.

[24] W. P. Smith, "Ecology of Glaucomys sabrinus: habitat, demography, and community relations," Journal of Mammalogy, vol. 88, no. 4, pp. 862-881, 2007.

[25] P. D. Weigl, The distribution of the flying squirrels, Glaucomys volans and Glaucomys sabrinus: an evaluation of the competitive exclusion idea [Ph.D. Dissertation], Duke University, Durham, NC, USA, 1969.

[26] J. N. Pauli, S. A. Dubay, E. M. Anderson, and S. J. Taft, "Strongyloides robustus and the northern sympatric populations of Northern (Glaucomys sabrinus) and Southern (G. volans) flying squirrels," Journal of Wildlife Diseases, vol. 40, no. 3, pp. 579$582,2004$.

[27] K. Krichbaum, C. G. Mahan, M. A. Steele, G. Turner, and P. J. Hudson, "The potential role of Strongyloides robustus on parasite-mediated competition between two species of flying squirrels (Glaucomys)," Journal of Wildlife Diseases, vol. 46, no. 1, pp. 229-235, 2010.

[28] W. M. Ford, C. A. Kelly, J. L. Rodrigue et al., "Late winter and early spring home range and habitat use of the endangered 
Carolina Northern flying squirrel in Western North Carolina," Endangered Species Research, vol. 23, pp. 73-82, 2014.

[29] S. W. Woudenberg, B. L. Conkling, B. M. O'Connell, E. B. LaPoint, J. A. Turner, and K. L. Waddell, "The forest inventory and analysis database: database description and user's manual version 4.0 for phase 2," Gen. Tech. Rep. RMRSGTR-245, U.S. Department of Agriculture, Forest Service, Rocky Mountain Research Station, Fort Collins, Colo, USA, 2010.

[30] R. K. Peet, T. R. Wentworth, M. P. Schafale, A. S. Weakley, and M. T. Lee, Carolina Vegetation Survey Database, Version 3.0, North Carolina Botanical Garden, Chapel Hill, NC, USA, 2013.

[31] F. W. Davis and S. Goetz, "Modeling vegetation pattern using digital terrain data," Landscape Ecology, vol. 4, no. 1, pp. 69-80, 1990.

[32] M. G. Turner, "Spatial and temporal analysis of landscape patterns," Landscape Ecology, vol. 4, no. 1, pp. 21-30, 1990.

[33] W. H. McNab, "Classification of local- and landscape-scale ecological types in the Southern Appalachian Mountains," Environmental Monitoring and Assessment, vol. 39, no. 1-3, pp. 215-229, 1996.

[34] P. V. Bolstad, W. Swank, and J. Vose, "Predicting Southern Appalachian overstory vegetation with digital terrain data," Landscape Ecology, vol. 13, no. 5, pp. 271-283, 1998.

[35] J. Franklin, "Predictive vegetation mapping: geographic modelling ofbiospatial patterns in relation to environmental gradients," Progress in Physical Geography, vol. 19, no. 4, pp. 474-499, 1995.

[36] C. J. Ulrey, Classification of the Vegetation of the Southern Appalachians, U.S. Department of Agriculture, U.S. Forest Service, Southeastern Research Station, Asheville, NC, USA, 1999.

[37] K. A. Yoke and J. C. Rennie, "Landscape ecosystem classification in the Cherokee National Forest, East Tennessee, USA," Environmental Monitoring and Assessment, vol. 39, no. 1-3, pp. 323338, 1996.

[38] R. B. Burnham and D. R. Anderson, Model Selection and Inference: A Practical Information-Theoretic Approach, Springer, New York, NY, USA, 1998.

[39] R. B. Daniels, H. J. Kleiss, and C. A. Ditzler, Soil Systems in North Carolina, North Carolina State Univeristy, Raleigh, NC, USA, 1999.

[40] North Carolina Wildlife Resources Commission, North Carolina Wildlife Action Plan, North Carolina Wildlife Resources Commission, Raleigh, NC, USA, 2005.

[41] G. J. Nowacki and D. Wendt, "The current distribution, predictive modeling, and restoration potential of red spruce in West Virginia," in Proceedings of the Conference on the Ecology and Management of High-Elevation Forests in the Central and Southern Appalachian Mountains, J. S. Rench and T. M. Schuler, Eds., pp. 163-178, U.S. Department of Agriculture, U.S. Forest Service, Northern Research Station, Evanston, Ill, USA, 2009.

[42] R. J. Reynolds, J. F. Pagels, and M. L. Fies, "Demography of northern flying squirrels in Virginia," in Proceeding of the Annual Conference of the Southeastern Association of Fish and Wildlife Agencies, vol. 53, pp. 340-349, 1999.

[43] R. E. Shanks, "Climate of the great smoky mountains," Ecology, vol. 35, pp. 354-361, 1954.

[44] S. A. Cain, "Ecological studies of the vegetation of the Great Smoky Mountains of North Carolina and Tennessee. Soil Reaction and Plant Distribution," Botanical Gazette, vol. 91, pp. 22-41, 1931.
[45] R. H. Whittaker, Vegetation of the Great Smoky Mountains, Ecological Monographs 26, 1956.

[46] L. G. Chafin and S. B. Jones Jr., "Community structure of two southern Appalachian boulderfields," Castanea, vol. 54, pp. 230-237, 1989.

[47] C. D. Oliver and B. C. Larson, Forest Stand Dynamics, John Wiley \& Sons, New York, NY, USA, 1996.

[48] T. A. Spies, "Ecological concepts and diversity of old-growth forests," Journal of Forestry, vol. 102, no. 3, pp. 14-21, 2004.

[49] M. A. Jenkins, "Vegetation communities of Great Smoky Mountains National Park," Southeastern Naturalist, vol. 6, no. 1, pp. 35-56, 2007.

[50] ESRI 2011, “ArcMap:Release 10," Environmental Systems Research Institute, Redlands, Calif, USA.

[51] D. Gesch, M. Oimoen, S. Greenlee, C. Nelson, M. Steuck, and D. Tyler, "The National Elevation Dataset," Photogrammetric engineering and remote sensing, vol. 68, no. 1, pp. 5-11, 2002.

[52] D. B. Gesch, “The national elevation dataset," in Digital Elevation Model Technologies and Applications: The DEM User's Manual, D. Maune, Ed., pp. 99-118, American Society for Photogrammetry and Remote Sensing, Bethesda, Md, USA, 2nd edition, 2007.

[53] M. P. Schafale and A. S. Weakley, Classification of the Natural Communities of North Carolina: Third Approximation, North Carolina Natural Heritage Program, Raleigh, NC, USA, 1990.

[54] R. M. Callaway and E. E. C. Clebsch, "A multivariate analysis of forest communities in the Western Great Smoky Mountains National Park," The American Midland Naturalist, vol. 118, no. 1, pp. 107-120, 1987.

[55] W. H. McNab, "A topographic index to quantify the effect of mesoscale landform on site productivity," Canadian Journal of Forest Research, vol. 23, no. 6, pp. 1100-1107, 1993.

[56] J. Jenness, "DEM surface tools for ArcGIS (surfacearea.exe). 2.1.305," Jenness Enterprises, 2013, http://www.jennessent.com/ arcgis/surface_area.htm.

[57] I. D. Moore, R. B. Grayson, and A. R. Ladson, "Digital terrain modelling: a review of hydrological, geomorphological, and biological applications," Hydrological Processes, vol. 5, no. 1, pp. 3-30, 1991.

[58] W. H. McNab, "Terrain shape index: quantifying effect of minor landforms on tree height," Forest Science, vol. 35, no. 1, pp. 91104, 1989.

[59] M. H. Graham, "Confronting multicollinearity in ecological multiple regression," Ecology, vol. 84, no. 11, pp. 2809-2815, 2003.

[60] R Core Team, R: A Language and Environment for Statistical Computing, R Foundation for Statistical Computing, Vienna, Austria, 2013, http://www.R-project.org/.

[61] W. N. Venables and B. D. Ripley, Modern Applied Statistics with S, Springer, New York, NY, USA, 4th edition, 2002.

[62] E. Vittinghoff, D. V. Glidden, S. Shiboski, and C. E. McCulloch, Regression Methods in Biostatistics, Springer, New York, NY. USA, 2005.

[63] E. Vittinghoff, D. V. Glidden, S. C. Shiboski, and C. E. McCulloch, Regression Methods in Biostatistics: Linear, Logistic, Survival, and Repeated Measures Models, Springer Science \& Business Media, 2012.

[64] H. Akaike, "Factor analysis and AIC," Psychometrika, vol. 52, no. 3, pp. 317-332, 1987. 
[65] J. W. McCombs, Geographic information systems topographic factor maps for wildlife management [M.S. Thesis], Virginia Polytechnice Institute and State University, Blacksburg, Va, USA, 1997.

[66] G. Narayanaraj, P. V. Bolstad, K. J. Elliott, and J. M. Vose, “Terrain and landform influence on Tsuga canadensis (L.) Carrière (Eastern Hemlock) distribution in the southern appalachian mountains," Castanea, vol. 75, no. 1, pp. 1-18, 2010.

[67] W. H. McNab and S. A. Browning, "Preliminary ecological classification of arborescent communities on the wine spring creek watershed, nantahala national forest," in Proceedings of the 7th Biennial Southern Silvicultural Research Conference, J. C. Brissette, Ed., Tech. Rep. SO-93, pp. 213-221, United States Department of Agriculture, Forest Service, Southern Forest Experiment Station, New Orleans, LA, USA, 1993.

[68] R. D. Flanigan, Predicting species composition in an eastern hardwood forest with the use of digitally derived terrain variables [M.S. thesis], West Virginia University, Morgantown, WVa, USA, 2010.

[69] E. L. Braun, Deciduous Forests of Eastern North America, MacMillan Publishing Co., New York, NY, USA, 1950.

[70] W. H. McNab, "Predicting forest type in Bent Creek Experimental Forest from topographic variables," in Proceedings from the 6th Biennial Southern Silvicultural Research Conference, pp. 496-504, Memphis, Tenn, USA, 1991.

[71] E. H. Frothingham, Timber Growing and Logging Practices in the Southern Appalachian Region, United States Department of Agriculture, U.S. Forest Service, Appalachian Forest Experiment Station, Washington, DC, USA, 1931.

[72] D. B. Vandermast, Disturbance and Long-Term Vegetation Change in the High-Elevation Deciduous Forest of Great Smoky Mountains National Park, University of North Carolina at Chapel Hill, Chapel Hill, NC, USA, 2005.

[73] C. Fowler and E. Konopik, "The history of fire in the Southern United States," Human Ecology Review, vol. 14, no. 2, pp. 165176, 2007.

[74] R. I. Bruck and W. P. Robarge, "Change in forest structure in the boreal montane ecosystem of Mount Mitchell, North Carolina," European Journal of Forest Pathology, vol. 18, pp. 357-366, 1988.

[75] J. S. Rentch, T. M. Schuler, G. J. Nowacki, N. R. Beane, and W. M. Ford, "Canopy gap dynamics of second-growth red sprucenorthern hardwood stands in West Virginia," Forest Ecology and Management, vol. 260, no. 10, pp. 1921-1929, 2010.

[76] R. H. Odom, W. M. Ford, J. W. Edwards, C. W. Stihler, and J. M. Menzel, "Developing a habitat model for the endangered Virginia northern flying squirrel (Glaucomys sabrinus fuscus) in the Allegheny Mountains of West Virginia," Biological Conservation, vol. 99, no. 2, pp. 245-252, 2001. 

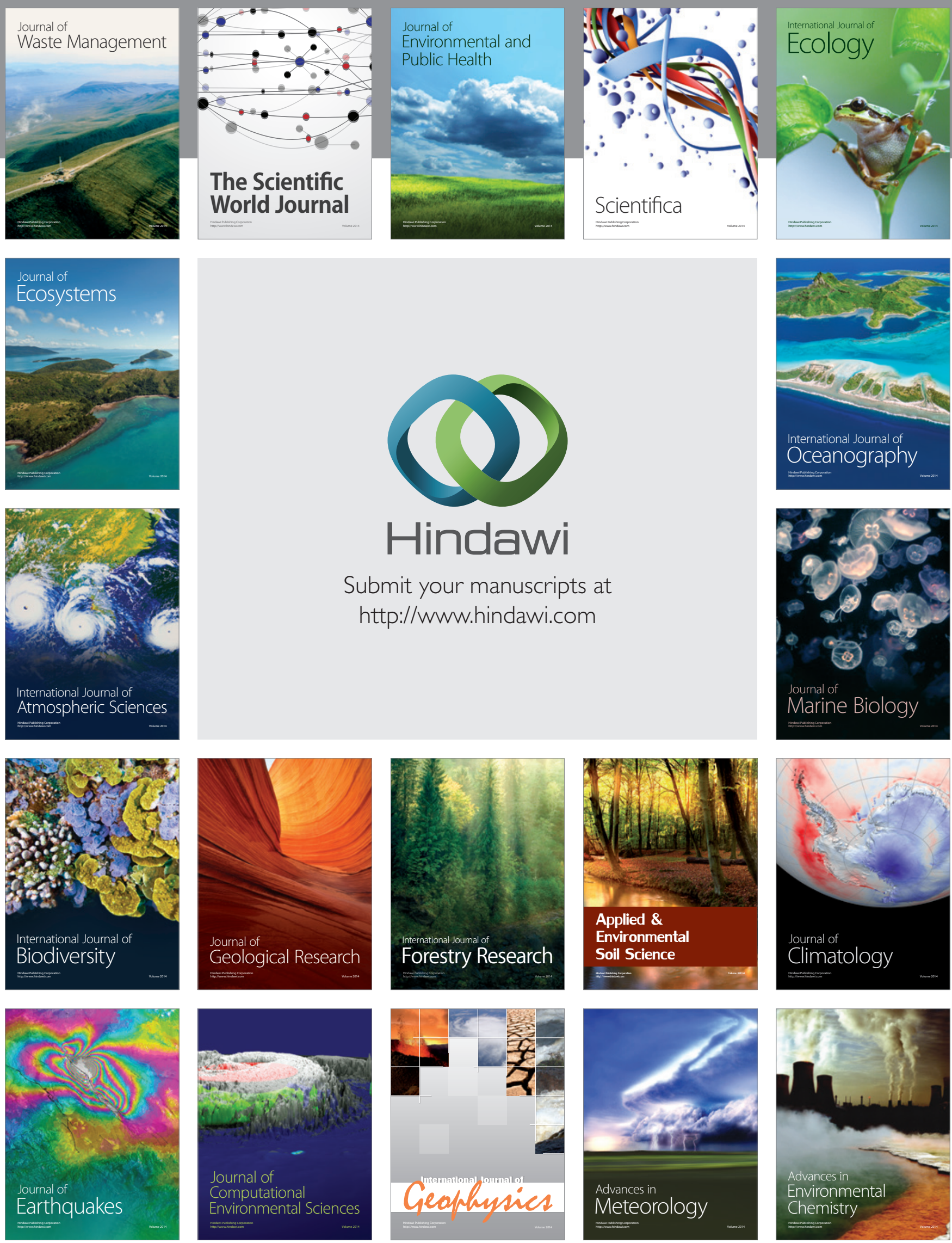